\title{
Morphological Evidence for Direct Interaction Between Gonadotrophin-Releasing Hormone Neurones and Astroglial Cells in the Human Hypothalamus
}

\author{
M. Baroncini, ${ }^{*} \dagger+$ C. Allet, ${ }^{*}$ D. Leroy, ${ }^{*}$ J.-C. Beauvillain, ${ }^{*}$ J.-P. Francke ${ }^{*} \dagger$ and V. Prevot ${ }^{*}$ \\ *Inserm, Jean-Pierre Aubert Research Center, U837, Development and Plasticity of the Postnatal Brain, Lille, France. \\ †Université de Lille 2, Faculté de Médecine, Laboratoire d'Anatomie, Institut de médecine prédictive et recherche thérapeutique, Lille, France. \\ $\ddagger$ CHU Lille, Clinique de Neurochirurgie, Lille, France.
}

\section{Journal of Neuroendocrinology}

Correspondence to:

Vincent Prevot, Inserm U837, Place de Verdun, 59045 Lille, Cedex, France

(e-mail: prevot@lille.inserm.fr).
In rodents, there is compelling evidence indicating that dynamic cell-to-cell communications involving cross talk between astroglial cells (such as astrocytes and specialised ependymoglial cells known as tanycytes) and neurones are important in regulating the secretion of gonadotrophin-releasing hormone $(\mathrm{GnRH})$, the neurohormone that controls both sexual maturation and adult reproductive function. However, whether such astroglial cell-GnRH neurone interactions occur in the human brain is not known. In the present study, we used immunofluorescence to examine the anatomical relationship between $\mathrm{GnRH}$ neurones and glial cells within the hypothalamus of five women. Double-staining experiments demonstrated the ensheathment of GnRH neurone perikarya by glial fibrillary acidic protein (GFAP)-immunoreactive astrocyte processes in the periventricular zone of the tuberal region of the hypothalamus. GFAP immunoreactivity did not overlap that of $\mathrm{GnRH}$ at the $\mathrm{GnRH}$ neurone's projection site (i.e. the median eminence of the hypothalamus). Rather, human $\mathrm{GnRH}$ neuroendocrine fibres were found to be closely associated with vimentin or nestin-immunopositive radial gial processes likely belonging to tanycytes. In line with these light microscopy data, ultrastructural examination of GnRH-immunoreactive neurones showed numerous glial cells in direct apposition to pre-embedding-labelled GnRH cell bodies and/or dendrites in the infundibular nucleus, whereas postembedding immunogoldlabelled GnRH nerve terminals were often seen to be enwrapped by glial cell processes in the median eminence. GnRH nerve button were sometimes visualised in close proximity to fenestrated pituitary portal blood capillaries and/or evaginations of the basal lamina that delineate the pericapillary space. In summary, these data demonstrate that GnRH neurones morphologically interact with astrocytes and tanycytes in the human brain and provide evidence that glial cells may contribute physiologically to the process by which the neuroendocrine brain controls the function of GnRH neurones in humans.

Key words: LHRH, astrocytes, tancytes, neuroendocrine brain, reproduction, human.

doi: $10.1111 / j .1365-2826.2007 .01576 . x$
Gonadotrophin-releasing hormone $(\mathrm{GnRH})$ is the neurohormone controlling sexual maturation and adult reproductive function (1-3). In rodents, the cell bodies of $\mathrm{GnRH}$ neurones are diffusely distributed in the preoptic region; in primates, including humans, they are also present in the tuberal region of the hypothalamus. The neuroendocrine fraction of $\mathrm{GnRH}$ neurones sends axons to the median eminence of the hypothalamus, where they release their neurohormone into the pituitary portal vasculature. On reaching the anterior, pituitary $\mathrm{GnRH}$ elicits the secretion of the gonadotrophins luteinising hormone and follicle-stimulating hormone that stimulate gametogenesis and gonadal steroids secretion, and thus support reproductive physiology.

Because GnRH neurones are the final common pathway for the central control of reproduction, their activity is regulated by a complex array of excitatory and inhibitory transsynaptic inputs (4-9). Noticeably, both $\mathrm{GnRH}$ neurones and the multiple neuronal 
networks involved in the control of $\mathrm{GnRH}$ secretion can be subjected to the direct modulatory influence of gonadal steroids $(10,11)$. However, it is becoming increasingly clear from experiments conducted in rodents that, in addition to these transsynaptic regulatory mechanisms, cell-cell interactions involving non-neuronal cells, such as astrocytes and specialised ependymoglial cells known as tanycytes, might be of critical importance for the regulation of $\mathrm{GnRH}$ secretion in females (12-16).

Glial cell processes abundantly appose the GnRH cell membrane in both rodents and nonhuman primates and at both $\mathrm{GnRH}$ perikarya and $\mathrm{GnRH}$ axon terminals (17-23). Whether $\mathrm{GnRH}$ neurones exhibit strong associations with astroglial cells in the human brain is not known. To provide an anatomical basis for the potential direct interaction of glial cells with $\mathrm{GnRH}$ neurones in the human hypothalamus, morphological studies were conducted using postmortem human material.

In the present study, double-immunofluorescence was used to examine whether astroglia processes from the tuberal region of the hypothalamus make close appositions to $\mathrm{GnRH}$ perikarya, as well as to its nerve terminals. In a second experiment, the glial ensheathment of $\mathrm{GnRH}$ neurones was examined by electron microscopy.

\section{Materials and methods}

\section{Tissue}

Brains of five women were obtained from autopsies at 6-48 $\mathrm{h}$ postmortem (Table 1). A review of medical records indicated that specimens were obtained from individuals with no neurological or neuroendocrinological disorder (Table 1). The brain samples were taken from patients that donated bodies to Science in compliance with the French laws on bioethics. Structures inside and outside the human brain were identified by reference to an atlas of the human brain (24).

\section{Fluorescent immunostaining}

After whole brain removal, blocks of $20 \mathrm{~mm}$ per side encompassing the hypothalamus were harvested with the optic chiasm as the anterior limit and the mamillary bodies as the posterior limit. Hypothalami were immersion fixed in $4 \%$ paraformaldehyde in $0.1 \mathrm{~m}$ phosphate buffer $(\mathrm{pH} 7.4)(\mathrm{PB})$ for 1 week, cryoprotected in 20\% sucrose in PB containing 0.9\% sodium chloride (PBS) for $48 \mathrm{~h}$, embedded in Tissue Tek (Miles, Elkhart, IN, USA) and

Table 1. Clinicopathologic Data.

\begin{tabular}{lllll}
\hline Number & Sex & $\begin{array}{l}\text { Age } \\
\text { (years) }\end{array}$ & $\begin{array}{l}\text { Postmortem } \\
\text { delay }(\mathrm{h})\end{array}$ & Cause of death \\
\hline Ha07 & Female & 67 & 24 & $\begin{array}{l}\text { Ano-rectal cancer with } \\
\text { hepatic metastases } \\
\text { Ha08 }\end{array}$ \\
& Female & 76 & 36 & $\begin{array}{l}\text { Renal insufficiency on } \\
\text { peritonitis by duodenal } \\
\text { perforation }\end{array}$ \\
Ha011 & Female & 89 & 32 & $\begin{array}{l}\text { Cardio-respiratory failure } \\
\text { Ha012 }\end{array}$ \\
Fa150 & Female & 88 & 48 & $\begin{array}{l}\text { Coronary thrombosis } \\
\text { Cardio-respiratory failure }\end{array}$ \\
\hline
\end{tabular}

Table 2. Primary Antibodies Used in the Study.

\begin{tabular}{|c|c|c|c|c|c|}
\hline Antigen & Host & Code & Dilution & References & Specificity \\
\hline $\mathrm{GnRH}$ & Rabbit & - & $1: 1000$ & (29) & (29) \\
\hline GFAP & Mouse & Clone G-A-5 & $1: 500$ & Sigma, France & (71) \\
\hline GFAP & Rabbit & Nr. Z 0334 & $1: 500$ & $\begin{array}{l}\text { DAKO Cytomation, } \\
\text { Denmark }\end{array}$ & (72) \\
\hline Vimentin & Mouse & Nr. M 0725 & $1: 1000$ & $\begin{array}{l}\text { DAKO Cytomation, } \\
\text { Denmark }\end{array}$ & (73) \\
\hline Nestin & Mouse & MAB1259 & $1: 250$ & $\begin{array}{l}\text { REtD Systems, } \\
\text { Germany }\end{array}$ & $\begin{array}{l}\text { RED Systems, } \\
\text { Germany }\end{array}$ \\
\hline
\end{tabular}

GnRH, gonadotrophin-releasing hormone; GFAP, glial fibrillary acidic protein.

frozen in liquid nitrogen. Coronal cryostat sections (14 $\mu \mathrm{m})$ were mounted on chrome-alum-gelatin coated slides, air-dried, and subjected to immunofluorescent stainings using a procedure described previously $(25,26)$. Briefly, sections were incubated for $10 \mathrm{~min}$ in LKPBS (KPBS $0.02 \mathrm{~m}$ with $0.3 \%$ of triton $100 \mathrm{X}$ and $2 \%$ of normal goat serum) to block the nonspecific sites. Sections were then incubated for one night at $4{ }^{\circ} \mathrm{C}$ with $250 \mu$ l of primary antibodies diluted in LKPBS. The characteristics of the primary antibodies used are shown in Table 2. After rinsing, secondary antibodies (250 $\mu$ l) were deposited on sections and incubated at room temperature (RT) for $1 \mathrm{~h}$. Goat antirabbit Alexa Fluor $488(1: 400)$ and goat antimouse Alexa Fluor 546 ( $1: 400)$ were obtained from Molecular Probes (Eugene, OR, USA). Cell nuclei were stained with $0.02 \%$ Hoechst 33258 bi-benzimidine (Molecular Probes). Importantly, to avoid the strong autofluorescence caused by lipofuscin granules usually present in adult human brain tissue, sections were immersed in a solution of 0.3\% Sudan Black B (Sigma, St Quentin Fallavier, France) in 70\% ethanol for $10 \mathrm{~min}$ (27). This treatment completely blocked autofluorescence. Sections were then coverslipped in PermaFluor medium (Immunon, Pittsburg, PA, USA). Control sections were incubated in the absence of primary antibody.

Immunofluorescent images were acquired using a DC300FX camera (Leica, Nussloch, Germany) attached to a DMRB microscope (Leica) through FW4000 software (Leica) with $\times 20$ (numerical aperture 0.5 ) or $\times 40,0.7$ Plan Fluotar objectives Confocal images were captured using a TCS SP confocal system (Leica). For illustration purposes, photomontages of the median eminence were prepared with the help of Photoshop CS2 (Adobe Systems, San Jose, CA, USA) using 30-60 digitised images acquired with a $\times 20$ objective.

\section{Electron microscopy}

A female brain with a 6 -h postmortem delay was subjected to intracerebroventricular injection of $10 \mathrm{ml}$ of $2 \%$ paraformaldehyde, $0.2 \%$ picric acid and $0.1 \%$ glutaraldehyde in $0.1 \mathrm{M} \mathrm{PB} \mathrm{pH} 7.4$ to prior dissection. The median eminence and the periventricular zone of the tuberal region were then harvested and immersed overnight in the same fixative solution.

\section{Pre-embedding immunostaining}

The periventricular zone of the tuberal region was sliced coronally (60 $\mu \mathrm{m})$ with a vibratome in $0.1 \mathrm{~m}$ PBS. Floating sections were subsequently processed for diaminobenzidine immunohistochemistry, slightly modified from a previously described method (28). Briefly, sections were blocked in PBS with 0.05\% Triton X-100 (Sigma), 1\% bovine serum albumin (BSA) and 10\% normal goat serum (NGS) for $1 \mathrm{~h}$ at RT before incubation with rabbit antiGnRH (1:500) (29) in PBS with $1 \%$ BSA and $10 \%$ NGS overnight at $4{ }^{\circ} \mathrm{C}$ with gentle rocking. Sections were extensively washed in PBS and exposed 
to biotinylated goat IgGs antirabbit IgGs (1:200, Jackson Immunoresearch Laboratories, West Grove, PA, USA) in PBS with 1\% BSA and 10\% NGS for $2 \mathrm{~h}$ at RT and then with avidin-peroxidase (Vector laboratories, Burlingame, CA, USA) for $1 \mathrm{~h}$ at RT. Finally, $5 \mathrm{mg} / \mathrm{ml}$ of $3,3^{\prime}$-diaminobenzidine tetrahydrochloride (Research Organics Inc., Cleveland, $\mathrm{OH}, \mathrm{USA}$ ) was added on sections in the presence of $0.01 \% \mathrm{H}_{2} \mathrm{O}_{2}$ in $0.1 \mathrm{M}$ Tris buffer $\mathrm{pH} 7.6$ for $10 \mathrm{~min}$ at $\mathrm{RT}$ to create an electron-dense enzymatic reaction product. Slices were then subjected to $1 \% \mathrm{OsO}_{4}$ in phosphate buffer for 20 min at RT, dehydrated and flat embedded in Araldite (Huntsman, Everberg, Belgium). Semithinsections (1-2 $\mu \mathrm{m}$ thick) were used to progressively approach GnRH-immunoreactive neurones. Ultrathin sections (80-90 nm thick) were collected on Parlodion 0.8\% isoamylacetate-coated 100 mesh nickel grids (Electron Microscopy Sciences, Fort Washington, PA, USA) and counterstained with uranyl acetate and lead citrate before observation on a Zeiss transmission electron microscope 902 (Leo, Rueil-Malmaison, France).

\section{Postembedding immunostaining}

Subsequent to the aforementioned prefixation, the piece of tissue containing the median eminence was postfixed for $1 \mathrm{~h}$ at room temperature with $1 \%$ $\mathrm{OsO}_{4}$ in $\mathrm{PB}$. After dehydration, pieces of tissue were embedded in Araldite. Semithin sections (1-2 $\mu \mathrm{m}$ thick) were used to progressively approach and identify the portion of the median eminence where the ultrastructural studies were performed. To detect GnRH immunoreactivity, ultrathin sections (80$90 \mathrm{~nm}$ thick) collected onto nickel grids were treated using an immunogold procedure described previously $(21,25)$. Briefly, after a treatment with $\mathrm{H}_{2} \mathrm{O}_{2}$ (10\%; $8 \mathrm{~min}$ ) and a blocking step in TBS (0.1 M Tris; pH 7.4, $0.15 \mathrm{~m} \mathrm{NaCl}$ : TBS) containing $1 \%$ normal goat serum and $1 \%$ bovine albumin serum (TBSB, $10 \mathrm{~min}$ at RT), the grids were floated on a drop of the following reagents and washing solutions: (i) rabbit anti-GnRH $(1: 5000)$ in TBSB for $60 \mathrm{~h}$ at $4{ }^{\circ} \mathrm{C}$; (ii) TBS to remove excess antibodies $(3 \times 10 \mathrm{~min})$; (iii) colloidal gold ( $18 \mathrm{~nm})$ labelled goat anti-rabbit immunoglobulins (Jackson Immunoresearch Laboratories) $1: 20$ in TBS (0.1 m Tris; pH 7.4, 0. $5 \mathrm{~m} \mathrm{NaCl}$ ) for $90 \mathrm{~min}$ at RT; (iv) TBS $(3 \times 10 \mathrm{~min})$; and $(\mathrm{v})$ distilled water $(3 \times 10 \mathrm{~min})$. The sections were also counterstained with uranyl acetate and lead citrate before observation.

Photographs were taken at an original magnification of $\times 7000$; for illustration purposes, negatives were digitised with a Epson Expression 1680 Pro (Epson France S.A., Levallois Perret, France) and microphotograph montages were made using Photoshop CS2.

\section{Results}

Localisation of $\mathrm{GnRH}$ cell bodies and axon terminals in the periventricular zone of the tuberal region of the human hypothalamus

The localisation of $\mathrm{GnRH}$ expression was examined in the tuberal region of the human hypothalamus (Fig. 1A) using immunohistofluorescence. Neuronal perikarya immunoreactive for $\mathrm{GnRH}$ were not confined to specific nuclei, but were dispersed in the periventricular zone of the tuberal region, as previously described (30-34). Ten to $30 \mathrm{GnRH}$ neurones were analysed per hypothalamus. GnRH-immunoreactive perikarya were often found within the infundibular nucleus (inf) of the hypothalamus (Fig. 1B-D). These neurones were predominantly bipolar (Fig. 1B,E) and both their soma and dendrites were noticeably surrounded by numerous cells bearing small round nuclei (Fig. 1F-G). Within the median eminence of the hypothalamus, GnRH-immunoreactive fibres abundantly innervated the external zone where they densely outlined capillary loops (Fig. 1B-D).

\section{GnRH neurones are morphologically associated with GFAP-immunoreactive astrocytes at their cell body but not at their nerve terminals}

Using double immunostaining, GnRH neurones and GFAP-immunoreactive astrocytes in the periventricular zone of the tuberal region were examined for possible close appositions. As shown in Fig. 2(A-C), GnRH cell bodies are enwrapped in GFAP-immunoreactive processes emanating from cells that exhibit small and round nuclei. By contrast, the distribution of GFAP immunoreactivity within the median eminence did not overlap that of $\mathrm{GnRH}$ neuroendocrine fibres and/or neurovascular terminals (Fig. 2D-F).

GnRH neurones are morphologically associated with vimentin-immunoreactive glial cells both at their cell body and at their nerve terminals

To determine whether in the human median eminence, as in the rodent brain, $\mathrm{GnRH}$ axon fibres are tightly associated with glial processes belonging to specialised ependymoglial cells, known as tanycytes, we examined using a procedure similar to that described above immunoreactivities for $\mathrm{GnRH}$ and vimentin, which is an intermediate filament expressed by astrocytes in immature or dynamic conditions (35-37) and tanycytes (38). Figure 3(D-F) shows that $\mathrm{GnRH}$ fibres travel in close association with vimentin-immunoreactive tanycytic processes within the external layer of the median eminence. Unexpectedly, GnRH perikarya were also found in close apposition to vimentin-immunoreactive processes (Fig. 3A-C).

\section{Vimentin colocalise with GFAP in some hypothalamic astrocytes, but not in tanycytic endfeets}

To determine whether GFAP-immunoreactive hypothalamic glial cells also colocalise vimentin, we performed additional double immunofluorescent studies. As shown in Fig. 4(A-C), only a very few hypothalamic astrocytes express both GFAP and vimentin in the periventricular zone of the tuberal region. Within the median eminence, superimposition of the GFAP and vimentin stainings revealed that expression of these cytoskeletal proteins overlapped in the internal layer (Fig. 4D-F). By contrast, the glial cell processes contacting the pial surface in the external zone of the median eminence were only immunoreactive for vimentin (Fig. 4D-F).

\section{$\mathrm{GnRH}$ axon terminals are in close association} with nestin-immunoreactive tanycytic processes

Because, unlike GFAP, vimentin cannot form intermediate filaments on its own (39), we next investigated whether nestin, another intermediate filament protein expressed in immature glial cells (40) was expressed in the human hypothalamus. Within the periventricular zone of the tuberal region, nestin-immunoreactivity was strikingly confined to the median eminence. In particular, antinestin antibody stained ependymal cells lining the floor of the third ventricle and projecting to the ventral surface of the brain (Fig. 5B) (i.e. tanycytes). Nestin-positive tanycytes had tapering processes that 

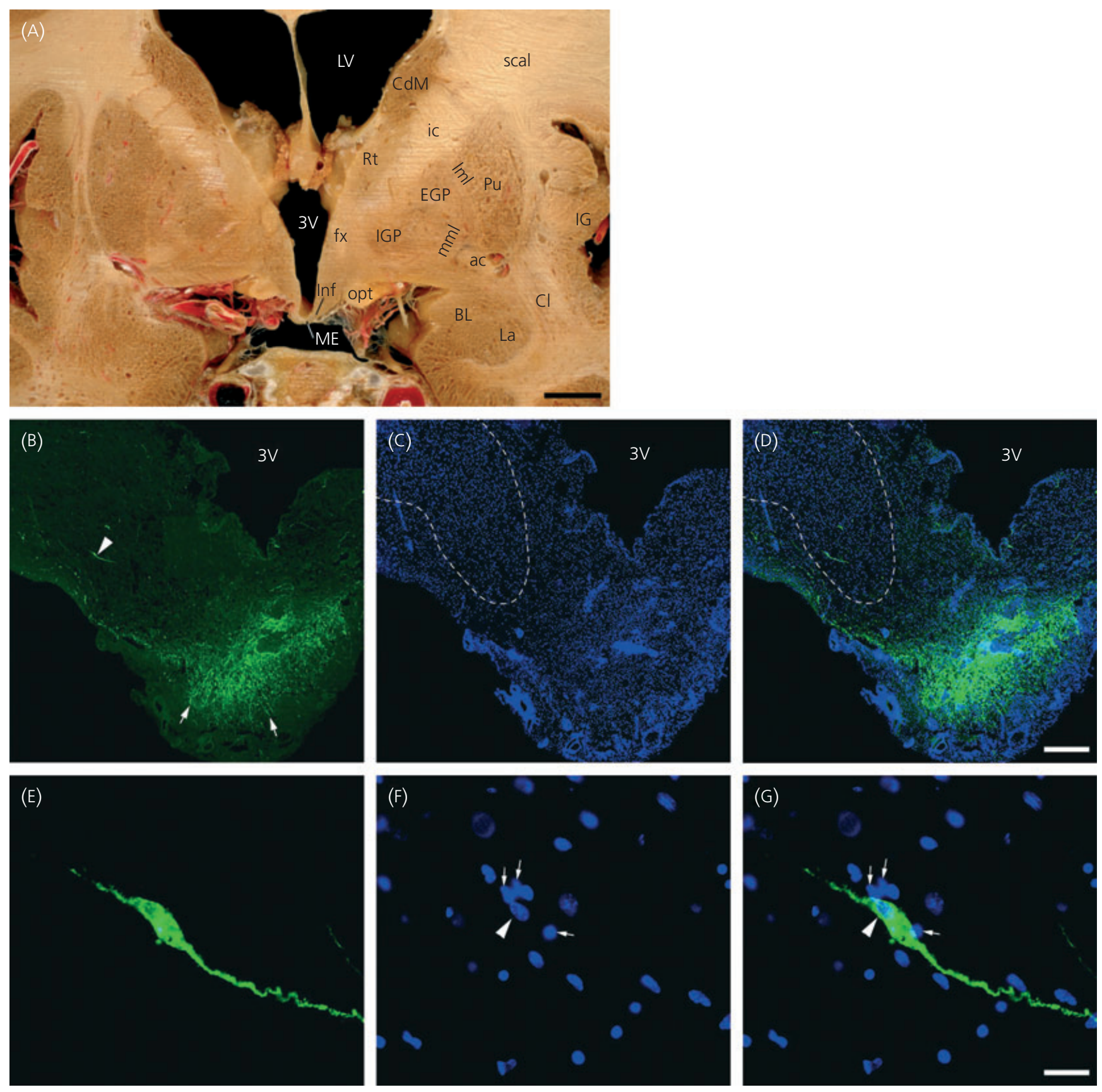

Fig. 1. Localisation of gonadotrophin-releasing hormone $(\mathrm{GnRH})$ immunoreactivity by fluorescent microscopy in the tuberal region of the human hypothala-

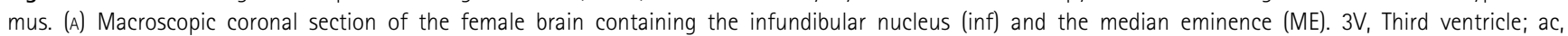
anterior commissure; $\mathrm{BL}$, basolateral amygdaloid nucleus; $\mathrm{Cdm}$, medial caudate nucleus; $\mathrm{Cl}$, claustrum; EGP, external globus pallidus; $\mathrm{fx}$, fornix; ic, internal capsule; IG, insular gyrus; IGP, internal globus pallidus; iml, internal medullary lamina of thalamus; La, lateral amygdaloid nucleus; LV, lateral ventricle; mml, medial medullary lamina of the globus pallidus; opt, optic tract; Pu, putamen; Rt, reticular thalamic nucleus; scal, subcallosal bundle. (B-D) Representative micrograph montages of $\mathrm{GnRH}$ immunoreactivity (green) in the tuberal region of the hypothalamus. Note the presence of a GnRH cell body (arrowhead) within the infundibular nucleus (doted lines) and of GnRH neuroendocrine axons (arrows) within the external zone of the median eminence. Cell nuclei are stained with Hoechst (blue, $C, D)$. $(E-G)$ Higher magnification of the $\mathrm{GnRH}$ immunofluorescent neurone shown in (B, arrowhead). Note the presence of numerous small nuclei-bearing cells (arrows) in close apposition to GnRH neurone's cell body and dendrite. Scale bars = $8 \mathrm{~mm}$ (A); $300 \mu \mathrm{m}$ (D), $20 \mu \mathrm{m}$ (G).

traversed the median eminence with an arching trajectory with end feet terminating close to the portal capillaries, thereby linking the third ventricle with the hypophysial vessels (Fig. 5B,E). In addition, the middle and the external parts of the median eminence (Fig. $5 \mathrm{E}$ ) contained positive cell bodies with short processes (Fig. 5E), also ending close to portal vessels (Fig. 5E). In accordance with the results presented in Figs $3(\mathrm{D}-\mathrm{F})$, double-label immunocytochemical studies for $\mathrm{GnRH}$ and nestin revealed numerous $\mathrm{GnRH}$ axons in 

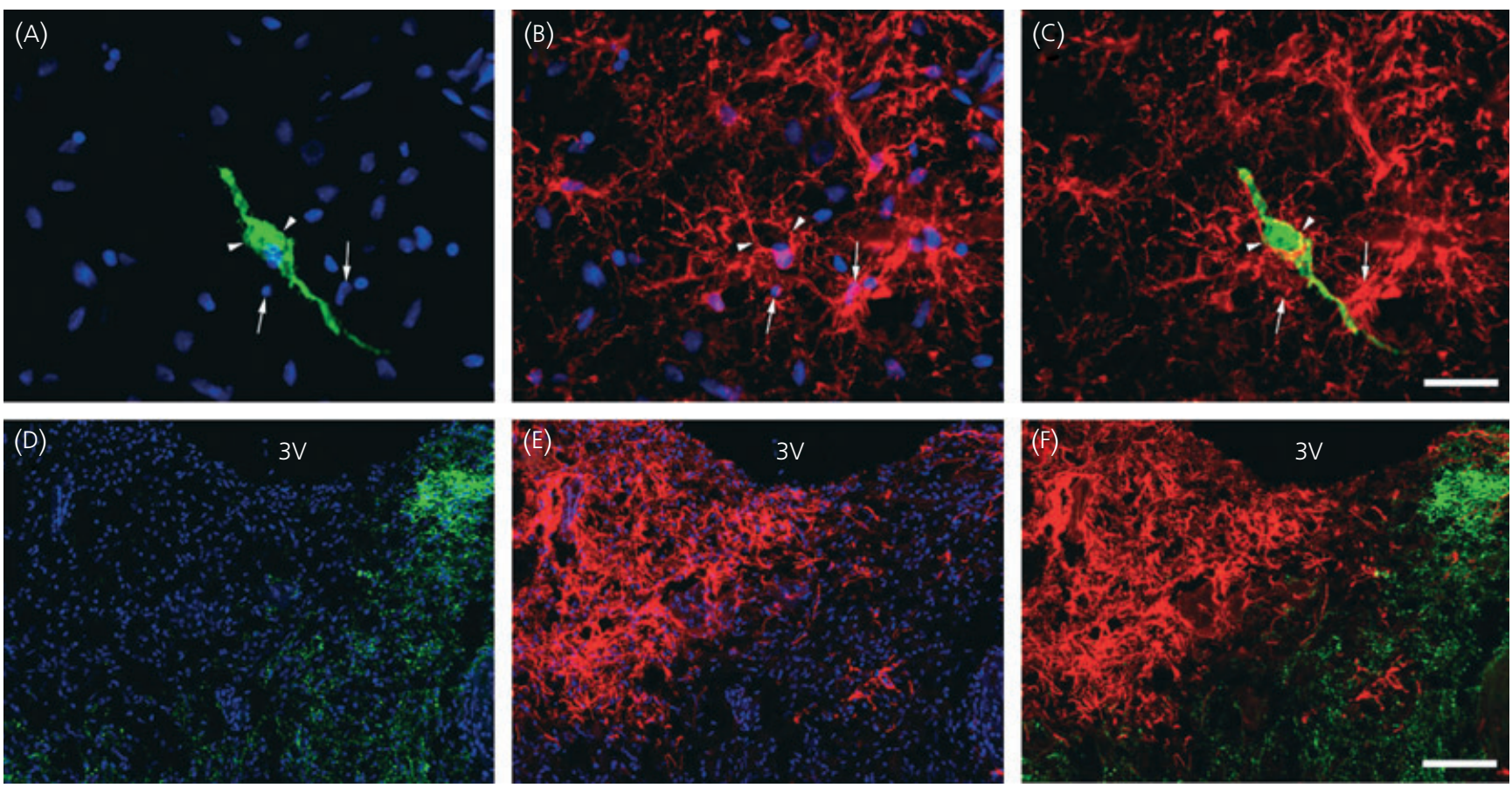

Fig. 2. Anatomical relationship between gonadotrophin-releasing hormone (GnRH)-immunoreactive neurones and glial fibrillary acidic protein (GFAP)-immunoreactive astrocytes in the tuberal region of the human hypothalamus. (A-C) Representative micrographs of GFAP-immunoreactive astrocytes (red, arrows) enwrapping the cell body and the dendrites of a GnRH-immunofluorescent neurone (green, arrowheads). (D-E) Representative micrograph montages of the distribution of GFAP (red) and GnRH (green) immunoreactivities within the median eminence. (c,F) Merged images of GFAP and GnRH immunoreactivities. Cell nuclei are stained with Hoechst (blue). Scale bars $=20 \mu \mathrm{m}$ (c), $100 \mu \mathrm{m}$ (F).

close contact with tanycytic processes in the external layer of the median eminence (Fig. 5). No cells in close association with $\mathrm{GnRH}$ cell bodies were immunoreactive for nestin.

\section{Ultrastructural analysis of the relationship between $\mathrm{GnRH}$ immunoreactivity and glial elements in the human hypothalamus}

To refine our analysis of glia-GnRH neurone morphological interactions, we undertook pre-embedding and postembedding immunocytochemical studies to visualise $\mathrm{GnRH}$ perikarya and $\mathrm{GnRH}$ axon terminals at the ultrastructural level, respectively. Although the tissues were not perfectly preserved due to the postmortem delay, the examination of $1 \mu \mathrm{m}$-thick semithin sections with the light microscope showed that $\mathrm{GnRH}$-immunopositive cell bodies were in direct contact with cells bearing small nuclei (Fig. 6A), which are seen to enwrap $\mathrm{GnRH}$ processes or immunoreactive sections of perikarya at the electron microscopic level (Fig. 6B). By contrast, in many cases, ultrastructural examination of the external zone of the median eminence showed that glial cell processes contacted immunogoldlabelled GnRH fibres (Fig. 7B,D). Interestingly, GnRH nerve endings were sometimes visualised near to fenestrated pituitary portal blood capillaries (Fig. $7 c, c^{\prime \prime}$ ) and/or evaginations of the pericapillary space (Fig. 7E). Gold particles were exclusively found over nerve terminals (Fig. 7B-E). Within axon terminals, GnRH-immunogoldlabelling was not restricted to large dense-core secretory granules, but was also seen in axoplasm and mitochondria, as shown previously in the monkey (17) and rat $(41,42)$.

\section{Discussion}

Astroglial cells morphologically interact with $\mathrm{GnRH}$ neurones in the human hypothalamus

The present study represents the first detailed morphological characterisation of neuro-glial interactions for $\mathrm{GnRH}$ neurones in the human brain. In keeping with previous observations demonstrating the ensheathment of both perikarya and neuroendocrine terminals of $\mathrm{GnRH}$ neurones by astroglia processes in rodents and nonhuman primates (17-23), our findings show that astrocytes and tanycytes are morphologically associated with $\mathrm{GnRH}$ neurones within the human hypothalamus. Previous work has established patterns of neuronal afferents to $\mathrm{GnRH}$ neurones (5) and documented action sites of oestrogen (43-45) within the human hypothalamus. However, we know remarkably little about how astroglia, which are key signalling components with the potential to modulate the way information is generated and disseminated within the brain (46), interact with $\mathrm{GnRH}$ neurones in the human hypothalamus. By using antibodies to intermediate filament proteins such as GFAP, we succeeded in visualising the anatomical relationship between $\mathrm{GnRH}$ neurones and astrocytes in the human hypothalamus. Our fluorescent microscopy results indicate that each individual $\mathrm{GnRH}$ cell 

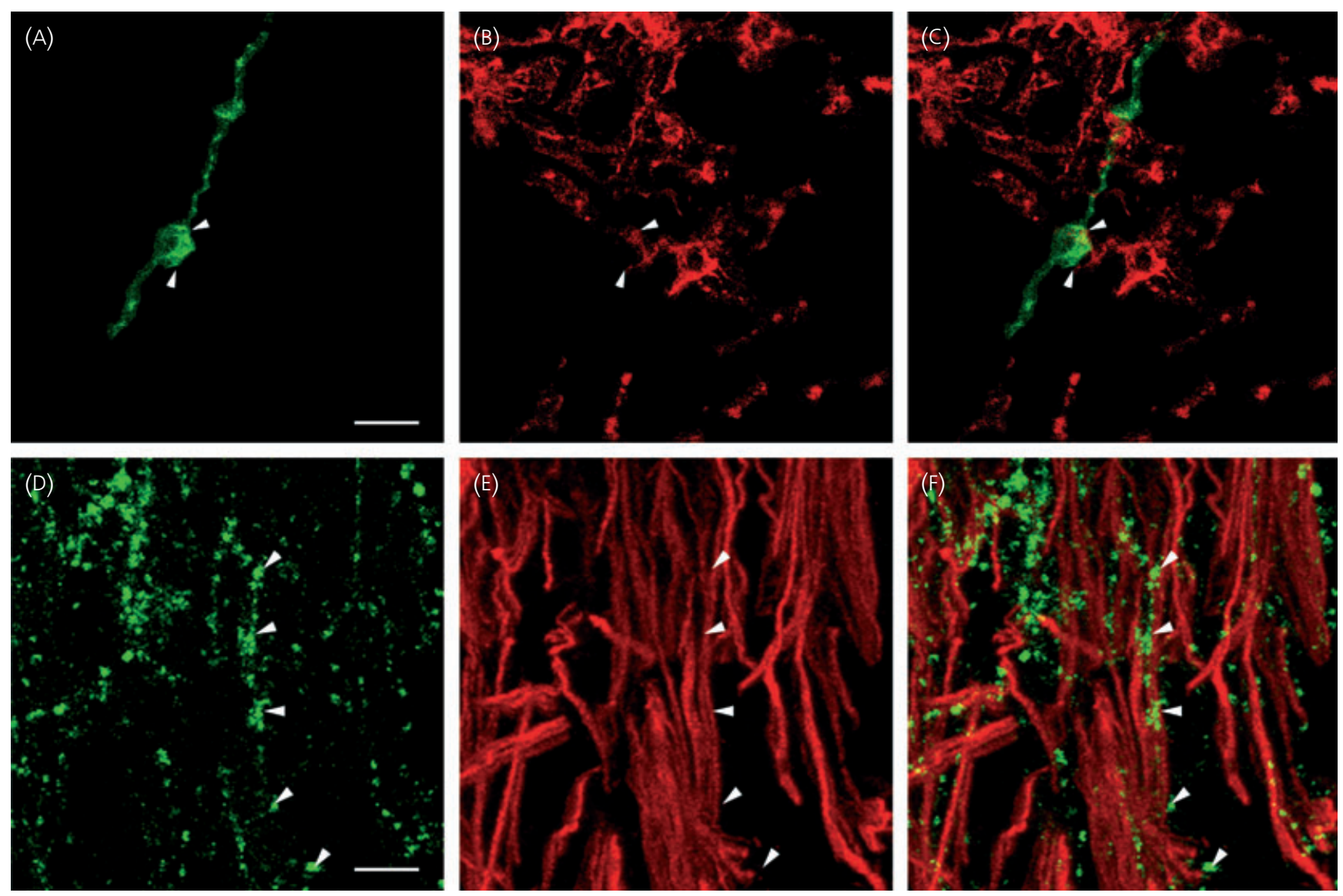

Fig. 3. Anatomical relationship between gonadotrophin-releasing hormone $(\mathrm{GnRH})$-immunoreactive neurones and vimentin-immunoreactive astrocytes and tanycytes in the tuberal region of the human hypothalamus. (A-C) Representative micrographs of a vimentin-immunoreactive astrocyte (red) engulfing the cell body of a GnRH-immunofluorescent neurone (green, arrowheads). (D-E) Representative micrographs of the distribution of vimentin and GnRH (arrowheads) immunoreactivities in the external part of the median eminence. (C,F) Merged images of vimentin and GnRH immunoreactivities. Scale bars $=20 \mu \mathrm{m}(\mathrm{A}), 5 \mu \mathrm{m}(\mathrm{D})$.

body is surrounded by several astrocytes that wrap themselves around their soma and dendrites. The existence of close contacts between $\mathrm{GnRH}$ perikarya and astrocytes was substantiated both by structural and ultrastructural analyses on semithin and ultrathin sections, respectively, in the human hypothalamus. At the $\mathrm{GnRH}$ neurone's projection site, astrocytes did not appear to interact with $\mathrm{GnRH}$ neuroendocrine terminals. Rather, our results show a spatial segregation of $\mathrm{GnRH}$ axons to GFAP-immunonegative territories in the median eminence that corresponds to its external part. By contrast, the external region of the median eminence was found to be strongly immunoreactive for vimentin, which is another intermediate filament protein only expressed in certain astroglial cells of the postnatal brain and, among them, modified ependymoglial cells known as tanycytes (38). Within the median eminence of the hypothalamus, tanycytes line the ventral portion of the wall of the third ventricle and send radial cell processes reaching the external part of the median eminence, where they establish contact with the endothelial wall of the portal vessels, via 'end-feet' specialisations (47). Our data show that, as found in rodents $(48,49)$, vimentin-immunoreactive tanycytic processes closely appose $\mathrm{GnRH}$ nerve terminals travelling down to the external layer of the median eminence in the human hypothalamus. Because, in contrast to
GFAP, vimentin cannot self-assemble into intermediate filament in vivo (39), we aimed to identify the expression of nestin, which is an additional intermediate filament associated protein expressed in immature astroglial cells (40) that requires heteropolymerisation with either GFAP or vimentin to form intermediate filament bundles in vivo (39), and which has recently been shown to be expressed in tanycytes of the median eminence in rodents $(50,51)$. Our immunofluorescent data show that heavy glial cell processes are intensely labelled for nestin within the human median eminence. These results thus suggest that vimentin and nestin are coassembled in the intermediate filaments expressed in tanycytes of the median eminence. As visualised with antibodies to vimentin, nestin immunoreactive radial fibres are tightly associated with $\mathrm{GnRH}$ neuroendocrine axons. The intimate relationship between $\mathrm{GnRH}$ axon terminals and glia processes was coroborated at the electron microscopy level using a postembedding immunogold labelling procedure in the human median eminence. Altogether, these results provide the exciting possibility that radial tanycyte processes constitute glial elements which, in addition to serving as the scaffolding for $\mathrm{GnRH}$ neuroendocrine axons, may provide a regulatory role for those neuroendocrine nerve endings in the adult human median eminence. 

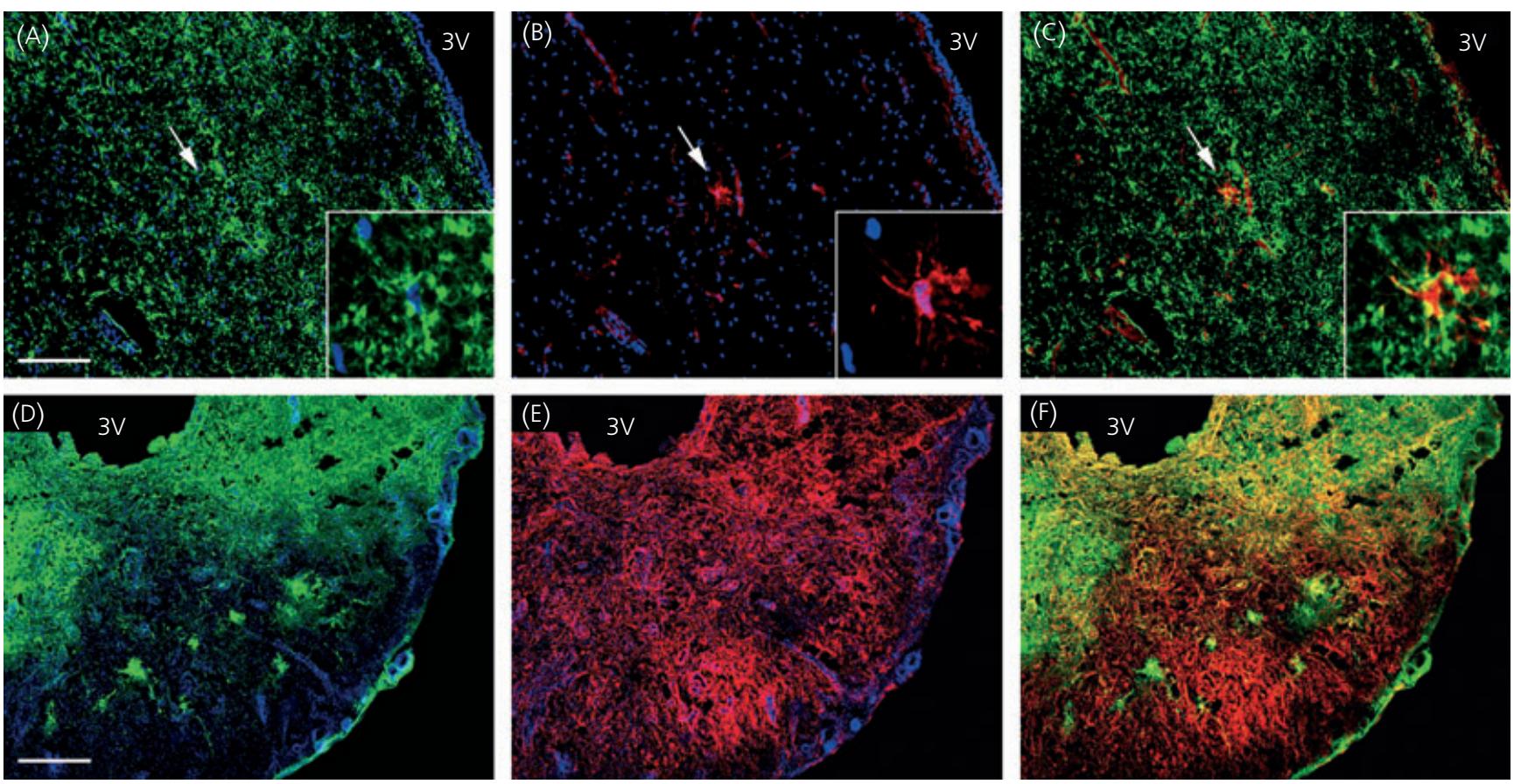

Fig. 4. Distribution of glial fibrillary acidic protein (GFAP) and vimentin immunoreactivities in the tuberal region of the human hypothalamus. (A-c) Representative micrographs of GFAP (green) and vimentin (red) fluorescent stainings in the periventricular zone. Note that among a wide GFAP-immunoreactive field only one astrocyte is immunoreactive for vimentin (arrow, inset). (D-F) Representative micrograph montages of GFAP and vimentin fluorescent stainings within the median eminence. $(C, F)$ Merged images of vimentin and GFAP immunoreactivities. Cell nuclei are stained with Hoechst (blue). 3V, Third ventricle. Scale bars $=100 \mu \mathrm{m}(\mathrm{A}), 300 \mu \mathrm{m}(\mathrm{D})$.

Hypothalamic neuroglial plasticity may modulate $\mathrm{GnRH}$ secretion

Hatton et al. (52) first demonstrated the importance of glial cells in the control of hypothalamic neurosecretion by documenting the plastic relationship that exists between astrocytes and vasopressin neurones. An increasing body of evidence suggests that astroglia are also functionally linked to $\mathrm{GnRH}$ neurones. In rodents, the direct access of $\mathrm{GnRH}$ neuroendocrine terminals to the vascular wall of the pituitary portal vessels in the external part of the median eminence is highly regulated by tanycytic processes that enwrap $\mathrm{GnRH}$ axon terminals $(18,19,21)$. At times of increased $\mathrm{GnRH}$ secretion (e.g. during the preovulatory surge of gonadotrophins), the terminals reach the endothelial wall due to, at least in part, retraction of the tanycytic end feet and/or evagination of the pericapillary space into the parenchyma (21). Interestingly, the ultrastructural examination of the external zone of the human median eminence undertaken in the present study showed that evaginations of the basal lamina that delineates the pericapillary space occasionally appear in the nervous tissue in the immediate proximity of GnRH nerve terminals. Notwithstanding that these data were obtained from an aged female hypothalamus, our results raise the possibility that the aforementioned morphofunctional plasticity could take place within the human median eminence during the menstrual cycle.

At GnRH perikarya, neuronal-glial interactions may also play a critical role in determining specific patterns of synapse formation during postnatal female sexual maturation, as well as participating in adult synaptic plasticity, as suggested by several nonhuman studies $(22,23,53,54)$. Intriguingly, our results show that, among those astrocytes ensheathing GnRH cell bodies, some of them are immunoreactive for vimentin. Because double-fluorescent staining experiments showed that vimentin-immunoreactive astrocytes within the tuberal region of the hypothalamus are only lithely labelled for GFAP, it appears unlikely that they correspond to reactive astrocytes which, in addition to a transient re-expression of vimentin, are known to dramatically increase their GFAP synthesis (55). Rather, the vimentin immunoreactive astrocytes could possibly serve a 'plastic' role by allowing changes in the apposition of astroglia processes to $\mathrm{GnRH}$ cell bodies, thus allowing synapses to form or to brake depending on environmental cues, as demonstrated for other neuroendocrine systems $(56,57)$. Intermediate filaments are highly polymorphic structures. This polymorphism allows for the constant modification of intermediate filaments structure in response to changes in cellular conditions triggered by extracellular signals (58). These unique physical properties bestow a critical function on intermediate filaments in the dynamic organisation of cytoarchitecture. It is then conceivable that expression of an increased array of intermediate filaments in a given cell may confer on it distinct cytodynamic properties.

A restriction on our findings holds for the possible influence of the endocrine status together with the postmortem period on the immunodetection of $\mathrm{GnRH}$ neurones and glial cells. However, previous studies by others have shown that the distribution and the 

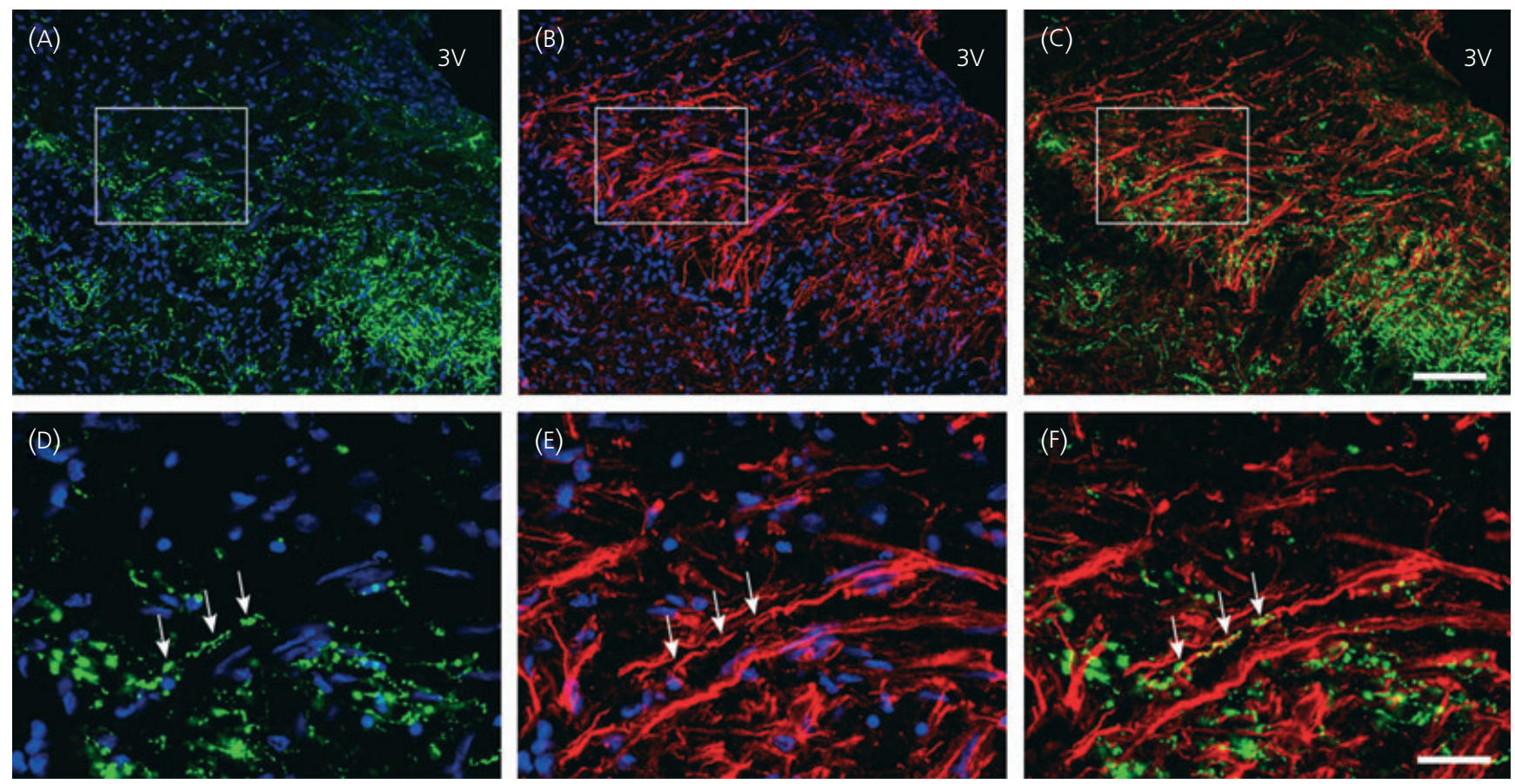

Fig. 5. Anatomical relationship between gonadotrophin-releasing hormone (GnRH)-immunoreactive neurones and nestin-immunoreactive tanycytes in the median eminence of the human hypothalamus. (A-C) Representative micrograph montages of nestin (red) and GnRH green (green) immunofluorescent labellings within the median eminence. (D-E) Higher magnification $(\times 40)$ of the distribution of nestin and GnRH (arrow) immunoreactivities in the external region of the median eminence. (c,F) Merged images of nestin and GnRH immunoreactivities. 3V, Third ventricle. Cell nuclei are stained with Hoechst (blue). Scale bars $=120 \mu \mathrm{m}$ (A), $30 \mu \mathrm{m}$ (D).
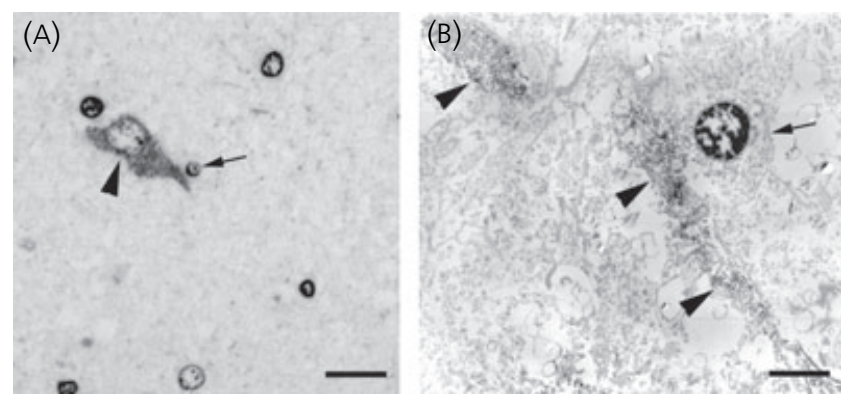

Fig. 6. Representative photomicrographs of a gonadotrophin-releasing hormone $(\mathrm{GnRH})$ neurone from the periventricular zone of the tuberal region of the hypothalamus of a female in a semithin (A) or ultrathin (B) section by light (A) or electron (B) microscopy, respectively. Expression of the GnRH peptide within the neurone is indicated by the presence of osmificated diaminobenzidine (black arrowheads). Astrocyte nuclei are present at the immediate proximity of perikarya and/or dendrites ( $A, B$, arrows). Astroglial processes $(B$, arrow) are present around dendrites or sections of the perikarya. Scale bars $=10 \mu \mathrm{m}(\mathrm{A}) ; 2.5 \mu \mathrm{m}$ (B). morphology of the GnRH neurones do not vary by the gender, age and postmortem delay ( $<48 \mathrm{~h}$ ) of the individuals (59). In addition, Rance et al. (60) showed that glial cell density, GFAP staining and $\mathrm{GnRH}$ neurone morphology were comparable before and after menopause in the human hypothalamus.

\section{Glia-to-neurone signalling and the neuroendocrine control of $\mathrm{GnRH}$ secretion in the mammalian brain}

There is now evidence that astroglial cells and $\mathrm{GnRH}$ neurones communicate via specific signalling pathways. These communication pathways operate by release of growth factors acting via serine-threonine kinase receptors, such as transforming growth factor (TGF)- $\beta_{1}$ (61-65), and growth factors signalling through receptors with tyrosine kinase activity including, among others, the epidermal growth factor (EGF)-related peptides, TGF- $\alpha$ and neuregulins (26, 66-68). Signalling through members of both TGF- $\beta$ and EGF families may account for part of the plastic remodelling that

Fig. 7. Representative micrographs of the structure and the ultrastructure of the median eminence of a woman by light (A) and electron microscopy (B-E), respectively. (A) Toluidin blue-stained semithin section of the median eminence illustrating the anatomical level at which ultrathin sections were collected to perform the electron microscopic analysis. (B) Representative electron micrograph montage of immunogold-labelled axon terminals (black arrowheads) embedded within an astroglia process. (c) Electron micrograph montage of a gonadotrophin-releasing hormone $(\mathrm{GnRH})$ immunoreactive terminal (black arrowhead) in the external zone of the median eminence in close proximity of a fenestrated (white arrow) capillary (Cap). A high magnification of the nerve terminal (black arrowhead) and of the fenestrated endothelium (end.) are shown in $\left(c^{\prime}\right)$ and $\left(c^{\prime \prime}\right)$, respectively. (D) Illustration of a GnRH nerve terminal (arrowhead) surrounded by tanycytic processes (tan.). (E) Representative microphotograph showing an evagination of the basal lamina delineating the pericapillary space (asterisk) towards a GnRH nerve terminal (arrowhead). Scale bars $=250 \mu \mathrm{m}(\mathrm{A}), 1 \mu \mathrm{m}\left(\mathrm{B}, \mathrm{C}^{\prime}, \mathrm{C}^{\prime \prime}, \mathrm{D}, \mathrm{E}\right), 1.5 \mu \mathrm{m}(\mathrm{C})$. 

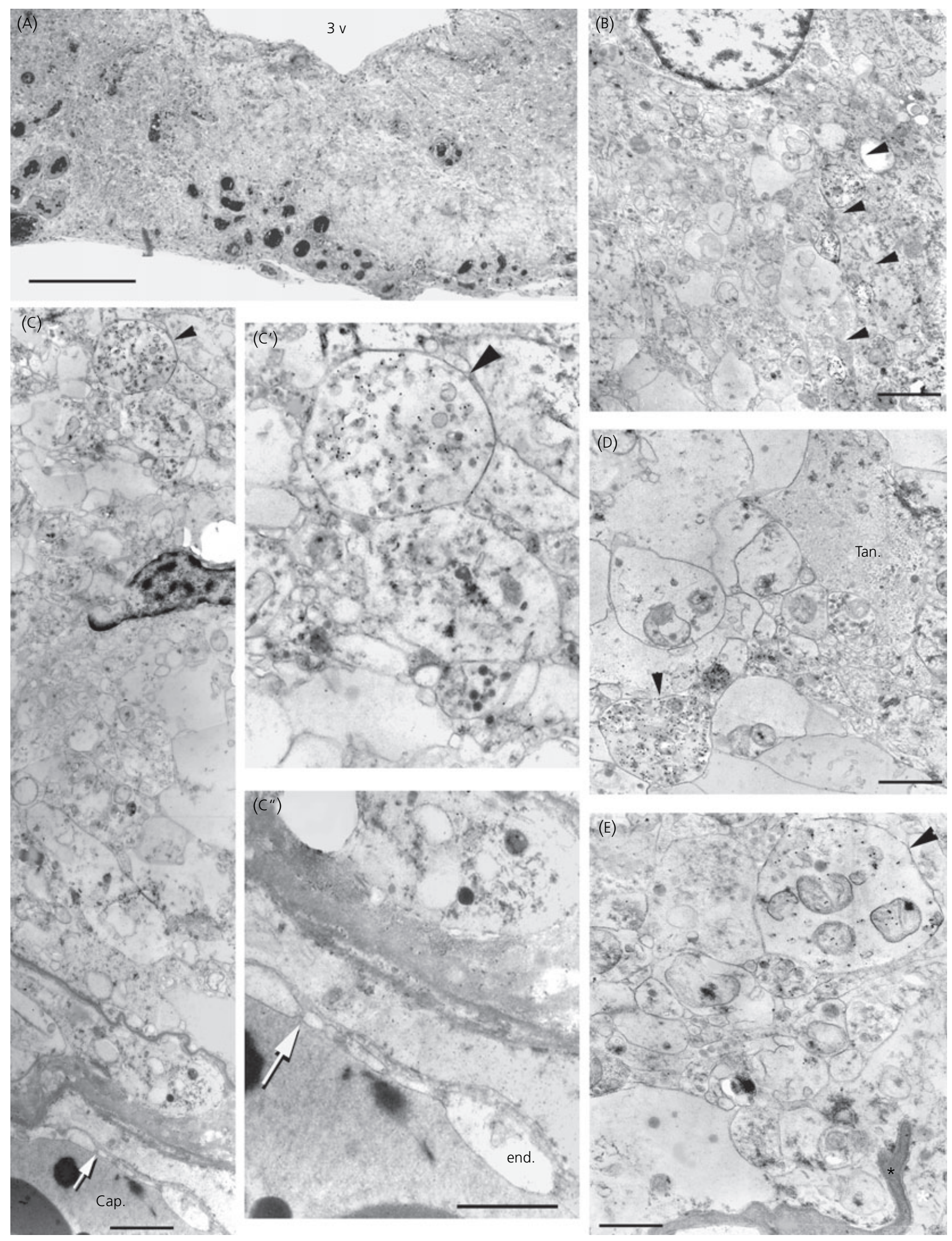
regulates the direct access of $\mathrm{GnRH}$ nerve terminals to the vascular wall and presumably modulates the release of $\mathrm{GnRH}$ into the portal vasculature during the reproductive cycle (65). In addition, TGF- $\alpha$ and neuregulin signalling pathways were recently shown to be critical for glial cells to engage neuro-glia interactions able to facilitate $\mathrm{GnRH}$ secretion both at the time of puberty and during adulthood $(26,68)$. Interestingly, in keeping with this concept, some human hypothalamic hamartomas associated with sexual precocity were shown to be rich in astroglial cells containing TG-F $\alpha$ (69). Supporting the notion that astroglial erbB signalling may also contribute physiologically to the process by which the neuroendocrine brain controls the function of $\mathrm{GnRH}$ neurones in humans are our recent in vitro studies showing that human hypothalamic astrocytes express all the functional erbB receptor signalling machinery (70).

\section{Conclusion}

Taken together, the present results show that GnRH neurones morphologically interact with astrocytes and tanycytes in the human brain and thus raise the exiting possibility that glial cells play an important role in the neuroendocrine control of $\mathrm{GnRH}$ secretion in humans.

\section{Acknowledgements}

This research was supported by the Institut National de la Santé et de la Recherche Médicale (Inserm, France) grant U816, the Université de Lille 2, the imaging Core of IFR114, I'Agence National pour la Recherche (ANR, France) and the Fondation pour la Recherche Médicale (Equipe FRM, France). C.A. was PhD student supported by a fellowship from the Centre Hospitalier Régional Universitaire (CHRU) and the Région Nord Pas de Calais.

Received: 1 December 2006, revised 15 February 2007, 5 April 2007, accepted 10 May 2007

\section{References}

1 Ojeda SR, Terasawa E. Neuroendocrine regulation of puberty. In: Pfaff $D$, Arnold A, Etgen A, Fahrbach $S$, Moss R, Rubin R, eds. Hormone, Brains and Behavior. New York, NY: Elsevier, 2002: 589-659.

2 Plant TM, Barker-Gibb ML. Neurobiological mechanisms of puberty in higher primates. Hum Reprod Update 2004; 10: 67-77.

3 Sisk CL, Foster DL. The neural basis of puberty and adolescence. Nat Neurosci 2004; 7: 1040-1047.

4 Brann DW, Mahesh VB. Excitatory amino acids: evidence for a role in the control of reproduction and anterior pituitary hormone secretion. Endocr Rev 1997; 18: 678-700.

5 Dudas B, Merchenthaler I. Three-dimensional representation of the neurotransmitter systems of the human hypothalamus: inputs of the gonadotrophin hormone-releasing hormone neuronal system. I Neuroendocrinol 2006; 18: 79-95.

6 Ojeda SR, Prevot V, Heger S. Regulation of puberty. Curr Opin Endocrinol Diabetes 2001; 8: 154-160.
7 Simerly RB. Wired for reproduction: organization and development of sexually dimorphic circuits in the mammalian forebrain. Annu Rev Neurosci 2002; 25: 507-536.

8 Terasawa E, Fernandez DL. Neurobiological mechanisms of the onset of puberty in primates. Endocr Rev 2001; 22: 111-151.

9 Parent AS, Matagne V, Bourguignon JP. Control of puberty by excitatory amino acid neurotransmitters and its clinical implications. Endocrine 2005; 28: 281-286.

10 Herbison AE. Multimodal influence of estrogen upon gonadotropinreleasing hormone neurons. Endocr Rev 1998; 19: 302-330.

11 Herbison $A E$, Pape JR. New evidence for estrogen receptors in gonadotropin-releasing hormone neurons. Front Neuroendocrinol 2001; 22: 292-308.

12 Dhandapani KM, Mahesh VB, Brann DW. Astrocytes and brain function: implications for reproduction. Exp Biol Med (Maywood) 2003; 228: 253260.

13 Garcia-Segura LM, McCarthy MM. Minireview: role of glia in neuroendocrine function. Endocrinology 2004; 145: 1082-1086.

14 Melcangi RC, Martini L, Galbiati M. Growth factors and steroid hormones: a complex interplay in the hypothalamic control of reproductive functions. Prog Neurobiol 2002; 67: 421-449.

15 Ojeda SR, Prevot V, Heger S, Lomniczi A, Dziedzic B, Mungenast A. Gliato-neuron signaling and the neuroendocrine control of female puberty. Ann Med 2003; 35: 244-255.

16 Prevot. V, De Seranno. S, Estrella. C. Glial-neuronal-endothelial interactions and the neuroendocrine control of GnRH secretion. In: Hertz L, ed. Non-Neuronal Cells of the Nervous System: Function and Dysfunction. Amsterdam: Elsevier, 2004: 199-214.

17 Durrant AR, Plant TM. A study of the gonadotropin releasing hormone neuronal network in the median eminence of the rhesus monkey (Macaca mulatta) using a post-embedding immunolabelling procedure. J Neuroendocrinol 1999; 11: 813-821.

18 King JC, Letourneau RJ. Luteinizing hormone-releasing hormone terminals in the median eminence of rats undergo dramatic changes after gonadectomy, as revealed by electron microscopic image analysis. Endocrinology 1994; 134: 1340-1351.

19 Kozlowski GP, Coates PW. Ependymoneuronal specializations between LHRH fibers and cells of the cerebroventricular system. Cell Tissue Res 1985; 242: 301-311.

20 Perera AD, Plant TM. Ultrastructural studies of neuronal correlates of the pubertal reaugmentation of hypothalamic gonadotropin-releasing hormone $(\mathrm{GnRH})$ release in the rhesus monkey (Macaca mulatta). J Comp Neurol 1997; 385: 71-82.

21 Prevot V, Croix D, Bouret S, Dutoit S, Tramu G, Stefano GB, Beauvillain JC. Definitive evidence for the existence of morphological plasticity in the external zone of the median eminence during the rat estrous cycle: implication of neuro-glio-endothelial interactions in gonadotropin-releasing hormone release. Neuroscience 1999; 94: 809819.

22 Romero MT, Silverman AJ, Wise PM, Witkin JW. Ultrastructural changes in gonadotropin-releasing hormone neurons as a function of age and ovariectomy in rats. Neuroscience 1994; 58: 217-225.

23 Witkin JW, Ferin M, Popilskis SJ, Silverman AJ. Effects of gonadal steroids on the ultrastructure of GnRH neurons in the rhesus monkey: synaptic input and glial apposition. Endocrinology 1991; 129: 1083-1092.

24 Mai JK, Assheuer J, Paxinos G. Atlas of the Human Brain. San Diego, CA: Academic Press, 1997.

25 De Seranno S, Estrella C, Loyens A, Cornea A, Ojeda SR, Beauvillain JC, Prevot V. Vascular endothelial cells promote acute plasticity in ependymoglial cells of the neuroendocrine brain. J Neurosci 2004; 24: 1035310363. 
26 Prevot $\mathrm{V}$, Rio C, Cho GJ, Lomniczi A, Heger S, Neville CM, Rosenthal NA, Ojeda SR, Corfas G. Normal female sexual development requires neuregulin-erbB receptor signaling in hypothalamic astrocytes. I Neurosci 2003; 23: 230-239.

27 Romijn HJ, van Uum JF, Breedijk I, Emmering J, Radu I, Pool CW. Double immunolabeling of neuropeptides in the human hypothalamus as analyzed by confocal laser scanning fluorescence microscopy. J Histochem Cytochem 1999; 47: 229-236.

28 Beauvillain JC, Tramu G, Mazzuca M. Ultrastructural demonstration of nerve endings containing a substance related to growth hormonereleasing factor in the guinea-pig paraventricular nucleus. Cell Tissue Res 1987; 248: 223-226.

29 Beauvillain JC, Tramu G. Immunocytochemical demonstration of LH-RH, somatostatin, and ACTH-like peptide in osmium-postfixed, resin-embedded median eminence. J Histochem Cytochem 1980; 28: 1014-1017.

30 Barry J. Characterization and topography of LH-RH neurons in the human brain. Neurosci Lett 1976; 3: 287-291.

31 Bugnon C, Bloch B, Fellmann D. Cyto-immunological study of the ontogenesis of the gonadotropic hypothalamo-pituitary axis in the human fetus. J Steroid Biochem 1977; 8: 565-575.

32 Dudas B, Mihaly A, Merchenthaler I. Topography and associations of luteinizing hormone-releasing hormone and neuropeptide Y-immunoreactive neuronal systems in the human diencephalon. J Comp Neurol 2000; 427: 593-603.

33 King JC, Anthony EL, Fitzgerald DM, Stopa EG. Luteinizing hormonereleasing hormone neurons in human preoptic/hypothalamus: differential intraneuronal localization of immunoreactive forms. J Clin Endocrinol Metab 1985; 60: 88-97.

34 Najimi $M$, Chigr $F$, Jordan $D$, Leduque $P$, Bloch $B$, Tommasi $M$, Rebaud $P$, Kopp N. Anatomical distribution of LHRH-immunoreactive neurons in the human infant hypothalamus and extrahypothalamic regions. Brain Res 1990; 516: 280-291.

35 Dahl D, Rueger DC, Bignami A, Weber K, Osborn M. Vimentin, the 57000 molecular weight protein of fibroblast filaments, is the major cytoskeletal component in immature glia. Eur J Cell Biol 1981; 24: 191-196.

36 Pixley SK, VJ. Transition between immature radial glia and mature astrocytes studied with a monoclonal antibody to vimentin. Brain Res 1984; 317: 201-209.

37 Voigt T. Development of glial cells in the cerebral wall of ferrets: direct tracing of their transformation from radial glia into astrocytes. J Comp Neurol 1989; 289: 74-88.

38 Pixley SK, Kobayashi $Y$, de Vellis J. A monoclonal antibody against vimentin: characterization. Brain Res 1984; 317: 185-199.

39 Eliasson C, Sahlgren C, Berthold CH, Stakeberg J, Celis JE, Betsholtz C, Eriksson JE, Pekny M. Intermediate filament protein partnership in astrocytes. J Biol Chem 1999; 274: 23996-24006.

40 Hockfield S, McKay RD. Identification of major cell classes in the developing mammalian nervous system. J Neurosci 1985; 5: 3310-3328.

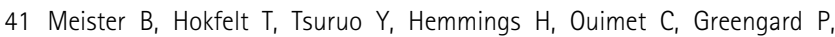
Goldstein M. DARPP-32, a dopamine- and cyclic AMP-regulated phosphoprotein in tanycytes of the mediobasal hypothalamus: distribution and relation to dopamine and luteinizing hormone-releasing hormone neurons and other glial elements. Neuroscience 1988; 27: 607-622.

42 Prevot V, Dutoit S, Croix D, Tramu G, Beauvillain JC. Semi-quantitative ultrastructural analysis of the localization and neuropeptide content of gonadotropin releasing hormone nerve terminals in the median eminence throughout the estrous cycle of the rat. Neuroscience 1998; 84: 177-191.

43 Donahue JE, Stopa EG, Chorsky RL, King JC, Schipper HM, Tobet SA, Blaustein JD, Reichlin $S$. Cells containing immunoreactive estrogen receptor-alpha in the human basal forebrain. Brain Res 2000; 856: 142151.
44 Kruijver FP, Balesar R, Espila AM, Unmehopa UA, Swaab DF. Estrogen receptor-alpha distribution in the human hypothalamus in relation to sex and endocrine status. J Comp Neurol 2002; 454: 115-139.

45 Kruijver FP, Balesar R, Espila AM, Unmehopa UA, Swaab DF. Estrogenreceptor-beta distribution in the human hypothalamus: similarities and differences with ER alpha distribution. J Comp Neurol 2003; 466: 251277.

46 Haydon PGGLIA. listening and talking to the synapse. Nat Rev Neurosci 2001; 2: 185-193.

47 Rodriguez EM, Blazquez JL, Pastor FE, Pelaez B, Pena P, Peruzzo B, Amat P. Hypothalamic tanycytes: a key component of brain-endocrine interaction. Int Rev Cytol 2005; 247: 89-164.

48 Prevot V. Glial-neuronal-endothelial interactions are involved in the control of GnRH secretion. J Neuroendocrinol 2002; 14: 247-255.

49 Silverman RC, Gibson MJ, Silverman AJ. Relationship of glia to GnRH axonal outgrowth from third ventricular grafts in hpg hosts. Exp Neurol 1991; 114: 259-274.

50 Chouaf L, Didier-Bazes M, Aguera M, Tardy M, Sallanon M, Kitahama K, Belin MF. Comparative marker analysis of the ependymocytes of the subcommissural organ in four different mammalian species. Cell Tissue Res 1989; 257: 255-262.

51 Xu Y, Tamamaki N, Noda T, Kimura K, Itokazu Y, Matsumoto N, Dezawa $M$, Ide $C$. Neurogenesis in the ependymal layer of the adult rat 3 rd ventricle. Exp Neurol 2005; 192: 251-264.

52 Hatton GI, Perlmutter LS, Salm AK, Tweedle CD. Dynamic neuronal-glial interactions in hypothalamus and pituitary: implications for control of hormone synthesis and release. Peptides 1984; 5 (Suppl. 1): 121-138.

53 Cashion AB, Smith MJ, Wise PM. The morphometry of astrocytes in the rostral preoptic area exhibits a diurnal rhythm on proestrus: relationship to the luteinizing hormone surge and effects of age. Endocrinology 2003; 144: 274-280.

54 Lehman MN, Karsch FJ, Robinson JE, Silverman AJ. Ultrastructure and synaptic organization of luteinizing hormone-releasing hormone (LHRH) neurons in the anestrous ewe. J Comp Neurol 1988; 273: 447-458.

55 Pekny M, Nilsson M. Astrocyte activation and reactive gliosis. Glia 2005; 50: 427-434.

56 Hatton Gl. Dynamic neuronal-glial interactions: an overview 20 years later. Peptides 2004; 25: 403-411.

57 Oliet SH, Piet R, Poulain DA, Theodosis DT. Glial modulation of synaptic transmission: insights from the supraoptic nucleus of the hypothalamus. Glia 2004; 47: 258-267.

58 Herrmann $H_{1}$ Aebi U. Intermediate filaments and their associates: multitalented structural elements specifying cytoarchitecture and cytodynamics. Curr Opin Cell Biol 2000; 12: 79-90.

59 Dudas B, Merchenthaler I. Close anatomical associations between betaendorphin and luteinizing hormone-releasing hormone neuronal systems in the human diencephalon. Neuroscience 2004; 124: 221-229.

60 Rance NE, McMullen NT, Smialek JE, Price DL, Young WS III Postmenopausal hypertrophy of neurons expressing the estrogen receptor gene in the human hypothalamus. J Clin Endocrinol Metab 1990; 71: 79-85.

61 Bouret S, De Seranno S, Beauvillain JC, Prevot V. Transforming growth factor beta1 may directly influence gonadotropin-releasing hormone gene expression in the rat hypothalamus. Endocrinology 2004; 145: 1794-1801.

62 Buchanan CD, Mahesh VB, Brann DW. Estrogen-astrocyte-luteinizing hormone-releasing hormone signaling: a role for transforming growth factor-beta(1). Biol Reprod 2000; 62: 1710-1721.

63 Melcangi RC, Galbiati M, Messi E, Piva F, Martini L, Motta M. Type 1 astrocytes influence luteinizing hormone-releasing hormone release from the hypothalamic cell line GT1-1: is transforming growth factor-beta the principle involved? Endocrinology 1995; 136: 679-686. 
64 Prevot V, Bouret S, Croix D, Takumi T, Jennes L, Mitchell V, Beauvillain JC. Evidence that members of the TGFbeta superfamily play a role in regulation of the $\mathrm{GnRH}$ neuroendocrine axis: expression of a type I serine-threonine kinase receptor for TGRbeta and activin in $\mathrm{GnRH}$ neurones and hypothalamic areas of the female rat. J Neuroendocrinol 2000; 12 : 665-670.

65 Prevot V, Cornea A, Mungenast A, Smiley G, Ojeda SR. Activation of erbB-1 signaling in tanycytes of the median eminence stimulates transforming growth factor beta1 release via prostaglandin E2 production and induces cell plasticity. J Neurosci 2003; 23: 10622-10632.

$66 \mathrm{Ma} \mathrm{YJ}$, Hill DF, Creswick KE, Costa ME, Cornea A, Lioubin MN, Plowman GD, Ojeda SR. Neuregulins signaling via a glial erbB-2-erbB-4 receptor complex contribute to the neuroendocrine control of mammalian sexual development. J Neurosci 1999; 19: 9913-9927.

67 Ojeda SR, Urbanski HF, Costa ME, Hill DF, Moholt-Siebert M. Involvement of transforming growth factor alpha in the release of luteinizing hormone-releasing hormone from the developing female hypothalamus. Proc Natl Acad Sci USA 1990; 87: 9698-9702.

68 Prevot V, Lomniczi A, Corfas G, Ojeda SR. erbB-1 and erbB-4 receptors act in concert to facilitate female sexual development and mature reproductive function. Endocrinology 2005; 146: 1465-1472.
69 Jung $H$, Carmel $P$, Schwartz MS, Witkin JW, Bentele KH, Westphal M, Piatt JH, Costa ME, Cornea A, Ma YJ, Ojeda SR. Some hypothalamic hamartomas contain transforming growth factor alpha, a puberty-inducing growth factor, but not luteinizing hormone-releasing hormone neurons. J Clin Endocrinol Metab 1999; 84: 4695-4701.

70 Sharif A, Duhem-Tonnelle V, Allet C, Baroncini M, Loyens A, Kerr-Conte J, Blond S, Ojeda SR, Junier MP, Prevot V. Characterization of ligandactivated erbB signalling pathways in human astrocytes. Soc Neurosci 2006; 733: 11/L1.

71 Debus $E_{1}$ Weber K, Osborn M. Monoclonal antibodies specific for glial fibrillary acidic (GFA) protein and for each of the neurofilament triplet polypeptides. Differentiation 1983; 25: 193-203.

72 Hansen SH, Stagaard M, Mollgard K. Neurofilament-like pattern of reactivity in human foetal PNS and spinal cord following immunostaining with polyclonal anti-glial fibrillary acidic protein antibodies. I Neurocytol 1989; 18: 427-436.

73 Osborn M, Debus E, Weber K. Monoclonal antibodies specific for vimentin. Eur J Cell Biol 1984; 34: 137-143. 